\title{
Signal-Induced Proliferation-Associated Protein 1
}

National Cancer Institute

\section{Source}

National Cancer Institute. Signal-Induced Proliferation-Associated Protein 1. NCI

Thesaurus. Code C48965.

Signal-induced proliferation-associated protein 1 (1042 aa, 112 kD) is encoded by the human SIPA1 gene. This protein is localized to the nucleus and functions as a GT Pase activator for the nuclear Ras-related regulatory proteins. 